\title{
EMOTIONAL LABOR DYNAMICS AS PRECURSORS TO MUNDANE VIOLENCE IN A PHILIPPINE CITY JAIL
}

\author{
Recebido em 1/04/2021, aprovado em 9/06/2021 \\ 10.30612/mvt.v8i14.15019 \\ Hannah Glimpse Nario-Lopez ${ }^{1}$
}

\begin{abstract}
This paper analyzes narratives on emotional labor among officers working in an overpopulated and undermanned city jail in the Philippines. Taking off from Hochschild (1983) and Crawley (2004) as theoretical departure points and using Sikolohiyang Pilipino as an approach in deploying institutional ethnography, I forward three arguments that enrich the understanding of emotion management dynamics in the carceral setting. First, emotional labor in the city jail is largely based on rank. Rank is a fixed navigation point where officers need to be in their "rightful place" (lugar) in interacting with and expressing emotions to others. Second, leadership regimes in forms of sistema (substandard yet acceptable ways of doing things) or kalakaran (corrupted sistema) also dictate emotion regimes among officers in the facility. And third, narratives of professionalism dominate accounts that normalize, reify, moralize, and even prize emotional laboring. In contrast to existing literature, data suggest that emotion management can be endowing, as it clarifies expectations and harmonizes relationships. Officers, in addition, claim that they are willing to endure emotional labor as it helps them to be more dutiful as a public servant. In fact, officers value emotional labor with a nationalist tone. With strong appreciation for emotional management in the narratives, I end with critical reflections and forwarded interrogations on the danger of moralizing emotional labor and recommend further investigation of its aspects that could lead to mundane violence.
\end{abstract}

Keywords: Jails and prisons. Emotion management. Prison sociology. Sociology of emotions.

\section{DINÂMICAS DO TRABALHO EMOCIONAL COMO PRECURSORAS DA VIOLÊNCIA EM UMA PRISÃO NAS FILIPINAS}

RESUMO: Este artigo analisa narrativas de trabalho emocional dentre agentes que trabalham em uma cadeia superpopulosa e má tripulado nas Filipinas. Partindo de Hochschild (1983) e e Crawley (2004) como pontos de partida teóricos e usando o estudo de caso Sikolohiyang Pilipino para desenvolver uma etnografia institucional, estabeleço três argumentos que enriquecem o gerenciamento das emoçóes no cárcere. Primeiro, o gerenciamento das emoçóes é baseado na configuraçáo carcerária. Segundo, esse trabalho é baseado na hierarquia, entendida como o lugar "correto" em

$1 \quad$ Hannah Glimpse Nario-Lopez earned her Bachelor and Master of Arts in Sociology from the University of the Philippines Diliman, where she is now teaching Philippine Contemporary Social Issues and Sociology of Deviant Behavior. She served as Youth Advisor at the Southeast Wyoming Juvenile Detention Center. Since her research on emotional labor among jail officers, has been providing skills training and consultancy services in two jail facilities in Metro Manila and advocating for a more equitable criminal justice system in the Philippines. You may reach her at: hcnario@up.edu.ph. 
que agentes devem estar ao interagir e expressar sentimentos para outras pessoas. Terceiro, narrativas de profissionalismo dominam relatos que nornalizam, reificam, moralizam e até mesmo gratificam trabalho emocional. Em contraste com a literatura existente, os dados sugerem que o gerenciamento das emoçóes pode ser adotado, haja vista que esclarecem expectativas e harmonizam relaçóes. Os(as) agentes, em adição, argumentam que podem desejar endurecer as emoçóes na medida em que isso os(as) auxilia a serem mais zelosos com seus deveres como funcionários públicos. Com efeito, agentes valorizam trabalho emocional com um tom nacionalista. Com foco no trabalho emocional a partir das narrativas, termino o artigo com reflexôes críticas, encaminhadas como interrogaçóes, sobre o perigo de moralizar o trabalho emocional e recomendo investigaçóes adicionais sobre seus aspectos que podem levar à violência mundana.

Palavras-chave: Cadeias e prisôes. Gerenciamento das emoçôes. Sociologia das prisôes. Sociologia das emoçôes.

\section{DINÁMICA DEL TRABAJO EMOCIONAL COMO PRECURSORES DE LA VIOLENCIA MUNDANA EN UNA CÁRCEL EN LAS FILIPINAS}

RESUMEN: Este artículo analisa las narrativas sobre el trabajo emocional entre los agentes que trabajan en una prisión municipal superpoblada y con poco personal en las Filipinas. Partiendo de Hochschild (1983) y Crawley (2004) como puntos de partida teóricos y utilizando Sikolohiyang Pilipino como un enfoque a la implantación en la etnografía institucional, presento tres argumentos que enriquecen la comprensión de la dinámica del manejo de las emociones en el entorno carcelario. Primero, el trabajo emocional en la cárcel se basa en gran medida en la clasificación. La clasificación es un punto de navegación fijo donde los oficiales deben estar en su "lugar correcto" para interactuar y expresar emociones a los demás. En segundo lugar, los regímenes de liderazgo en formas de sistema (formas de hacer las cosas deficientes pero aceptables) o kalakaran (sistema corrupto) también dictan los regímenes emocionales entre los oficiales en las instalaciones. Y tercero, las narrativas de profesionalismo dominan los relatos que normalizan, cosifican, moralizan e incluso valoran el trabajo emocional. En contraste con la literatura existente, los datos sugieren que el manejo de las emociones puede ser normalizador, ya que aclara las expectativas y armoniza las relaciones. Los oficiales, además, afirman que están dispuestos a soportar el trabajo emocional, ya que les ayuda a ser más celosos en sus obligaciones como servidores públicos. De hecho, los oficiales valoran el trabajo emocional con tono nacionalista. Con un fuerte aprecio por el manejo emocional en las narrativas, termino con reflexiones críticas, como preguntas, sobre el peligro de moralizar el trabajo emocional y recomiendo una investigación más profunda de sus aspectos que pueden conducir a la violencia mundana.

Palabras Clave: Cárceles y prisiones. Manejo de las emociones. Sociología penitenciaria. Sociología de las emociones. 


\section{INTRODUCTION}

Conditions inside Philippine prisons and jails are among the world's toughest. Facilities are packed with detainees awaiting trial, overstaying detainees, and reoffenders (BUSTINERA, 2016). In 2017, just months after self-confessed-mass-murderer Rodrigo Duterte's anti-drug platform won him the presidency, jail congestion ballooned from $300-450 \%$ to $512.75 \%$, mainly due to drug "surrenderers." These long-standing conditions affect how officers manage these facilities. Using Hochschild's (1979; 1983) emotional labor as a theoretical lens, Crawley put into cognition the expensive emotional costs of securing prison order by focusing on the narratives of officers - often excluded from study of carceral contexts. Drawing from Hochschild and Crawley, this article aims to contribute to the sociology of emotions and prison sociology by broadening heuristic applicability of emotional management in the context of material deprivations universal in Philippine facilities and other carceral contexts in the global south.

By putting prison sociology and sociology of emotions in conversation with each other, I forward the importance of emotion management in understanding the delivery of carceral service. And in doing so, I appraise jail work with the merit it deserves; to have a more holistic perception of how jails and prisons do not only serve as a place of detention, but are also places where relations emerge, dispositions are reproduced, and cultures are carried as lifestyles outside the facility. I argue that such deepened acknowledgement of prisons as social spaces could provide clues on why rehabilitation works in some places and not in others, leading us closer to resolving the global problem of recidivism.

The jail site of this study is one of the most densely populated city jails in Metro Manila, located in one of the largest cities in metropolis. The city has a total population of three million residents, composing a quarter of Metro Manila's total population. The city jail, however, was only built for less than a thousand persons. The jail only has the capacity to service a crime rate of 25.92 per 100,000 of the total population (2017). This seems like a workable number considering that the crime rate for this city in 2015 was 31 per 100,000 of the total population ${ }^{2}$. However, there is a huge number of the detainee population who have already overstayed, still awaiting trial, and therefore cannot be transferred to a prison facility. According to the United Nations (UN), for a 4.7 square-meters-per-person standard the ideal capacity of this jail is only 262 detainees. With more persons committed than released, the current state of housing of around 2800-2900 detainees is ten times the terms of the UN standard. This specific jail is not unique in the Philippine carceral context - the situation is the same across jails under the Bureau of Jail Management and Penology (BJMP) and prisons under the Bureau of Corrections (BuCor) ${ }^{3}$. If anything, its conditions are worse than other provincial jails, most especially when the spike in jail population hit 4,500 due to President Duterte's war on drugs in the mid of 2017. These impoverished conditions bear consequences in first, the delivery of human safekeeping and rehabilitation; and second, in the conditions by which social relations are carried out - understanding both is the impetus of this study. In my assessment, the city jail provides a good representation of the ravish situation that jail officers and Persons Deprived of Liberty (PDLs) need to endure daily and serves as a good precautionary tale for academic theorizing and policy engagement.

The methodological contribution of this piece is the use of Sikolohiyang Pilipino (SP, or Filipino Psychology), a culturally sensitive approach that gives primary importance to the distinctive character of Filipino psyche given the many nuances and layers that guide Filipino thinking, acting, behaving, and relation with each other. SP is both a method and a movement for indigenizing 
Filipino social sciences to overcome the limitations of western psychological models (CLEMENTE, 2011). Through guidance on how to best approach the carceral field and careful implementation of methods with utmost consideration to Filipino social relations within the peculiar space of the city jail, SP assisted how I secured my relations with my interlocutors - rendering analysis and theorization closer to the reality of Filipino experiences. This study augments the theoretical application of emotional labor and lays ground for Philippine prison sociology by providing a definitive take on how possibly the conditions of Philippine jails and prisons contribute to the practice of emotional labor in a jail operant in a specific cultural context.

I engaged with officers from a Philippine city jail over the course of five years, specifically on the following concerns: (a) their perception on their workplace's physical conditions; (b) their regard for other actors with whom they share the jail; (c) their sensitivities toward the consequences of jail conditions to social relations (TAVORY, 2020); (d) their consciousness of the interplay of occupational feeling rules and jail conditions to the character and process of the kind of emotional labor that they do, and; (e) their valuation of emotional labor.

\section{METHODOLOGY}

\section{ETHNOGRAPHY-INSPIRED DEPLOYMENT OF RESEARCH METHODS}

I took the distinctive elements of ethnography as an inspiration for this study's strategic use and deployment of a variety of research methods to maximize the opportunities to observe behavior, values, and practices as they surface from everyday life. Through the keenness in detail and sensitivity of approach that ethnography offers, in-depth descriptions in qualitative accounts are maximized (CRESWELL, 1998). The specific type of ethnography that I consider as this ethnographic inspiration is Institutional Ethnography (IE). IE frames the individual as a product of institutional processes (SMITH, 1987). Grahame (1998, p. 347) advanced the use of IE as a way to discover "how ideological accounts define those activities in relation to institutional imperatives and examining the broader social relations in which local sites of activity are embedded". Using IE as a toolkit, I attempted to go beyond everyday realities as a commonplace experience of the individual and sought to pin-down the problematique of the officers' every day in jail work. IE acted as a lens by which I formulate the problem and focus, and framework of this study, where emotions are not seen as exclusive yields of personalities but also a part and products of institutional processes.

The study was enriched through the ethnographic use of multiple methods to record various narratives, under different scenarios and with different matters of inquiry. This qualitative research employed the following methods: (a) a preliminary exploratory study on the Philippine criminal justice system, jail conditions, and jail work (done in 2014-2015); (b) continuous field visits to be more familiarized to the jail setting and gain sensitivities toward jail social relations (in 2016); and (c) 'main data gathering stage' (from 2017 until 2018, and then revisited in March 2019) which deeply interrogated the initial findings of the exploratory study and observations from subsequent jail visits. The iterative process of research writing and reanalysis was done throughout 2020 and early 2021. I found it very helpful that I did not solely rely on material gathered by previous 
studies and instead conducted an independent exploratory study to identify concerns, which this research focused on. The exploratory study also served as a precept to the consistent and frequent contact I maintained, which grounded how I navigated in the field and gathered data. As this study investigates the world of jail officers, IE became useful in immersion strategies, such as jail officers to first become familiarized with my presence and to gather field impressions to help myself become familiarized to the social setting and dynamics in interactive spaces. The "main data gathering stage" was composed of document analysis, participant observations, focus group discussions, and informal conversations - wherein I spent four to eight hours of workdays in the facility three to four times a week (NARIO-LOPEZ, 2017). IE further illuminated how I understood, interpreted, and analyzed field impressions, observations, and other forms of information by maintaining that all that I observed are products of how human actions are steadily organized by institutions. The prolonged and intense exposure provided me with sensitizing acuities, which I relied on in the construction of interview and focus group discussion guides and later in my analysis and refinement of arguments. There are at least 50 jail officers who became my interlocutors (CURATO, 2012) at different parts of the process. In all, this study draws from nearly five years' worth of inquiry, from 2014 to 2019.

\section{SIKOLOHIYANG PILIPINO AS METHODOLOGICAL APPROACH IN EXPLORING “FILIPINO EMOTIONS"}

The sociology of emotions has been criticized for methodological development lagging behind theoretical progress (FLAM; KLERES, 2015). These challenges researchers of emotions to review lines of inquiry, and fine-tune identification, collection, and interpretation of data. There must be conscious effort in making the research experience more constructive to respondents and the knowledge-generation process. Considering these, I approached the field with Sikolohiyang Pilipino (SP, Filipino Psychology) and thoughtfully related to all officers. As a move to decolonize my research lens, this study recognizes the character of deeply collectivist Filipino relationality (ENRIQUEZ, 1976 ; 1977) SP responds to the need to have a psychology of, about, and by Filipinos (YACAT, 2013) due to the limits of western models in understanding the Filipino. According to Enriquez (1976; 1977; 1994), there is uniqueness in the collectivist orientation in Filipino interpersonal relations. This kind of relationality is prominent in the nuancing of various kinds of relations, in: pakikipagkapwa-tao (being humane to each other), pakikisama (being in fellowship with each other), and pakikitungo (in utmost mutual respect with each other). Recognizing the Filipinos' collectivist orientation is important because it reflects their consciousness. In this research, SP is pivotal in approaching and analyzing how Filipino jail officers speak of and evaluate the jail conditions and assess their emotions at work with utmost regard for others and their group life. 
There are four strategies that I conducted to align this research to SP's sensitivities. ${ }^{4}$ First, I integrated the Categories of Social Interaction between the Researcher and the Participant (MARCELINO, 1990) as I transitioned from being a total outsider to a researcher with trustworthy relations amongst community members. I employed the following phases of research: pagmamashid (general scanning or looking around), pakikiramdam (sensing or feeling through), patanong-tanong (casual asking of questions), padalaw-dalaw (frequent visits), pakikitungo (relating with), pakikisalamuha (casual socializing), pakikilahok (participating with), pakikibagay (level of adjusting one's feelings and speech for others), pakikipagpalagayang-loob (earning trust), and pakikiisa (deeper participation and involvement). Second, SP's differentiation between hayag (expressed emotion) and saloobin (personal insight) guided how I inquired on the officers' emotions. By asking separately which feelings officers can express publicly and kept privately, I was able to traverse within this cultural distinction with the framework of emotion management. The distinction between hayag and saloobin is further enriched by Katriel's (2015) concept of 'discourse on emotion' to discuss how feelings are represented in conversations, sanctions, and appropriations. Third, I engaged and maintained native terminologies throughout the research to give respect to the verity that Filipinos opt for indigenous and indigenized terms to describe the things that they do and express the emotions they feel. This preference is foundational for the precise representation (PE-PUA; PROTACIOMARCELINO, 2000) of kamalayan (awareness), ulirat (consciousness), isip (mind), diwa (spirit), kalooban (feeling), and kaluluwa (soul). Lastly, via alluding to the understanding that Filipinos may opt for indigenized labels from the Filipino language to describe the things that they do and express the emotions they feel, analysis will focus on Filipino words and its colloquial use. Throughout this research, translation of terms in the closest English word will be provided but if no other technical vocabulary sufficiently represents the emotion expressed by the participants, explanations would be done based on how it was exactly said in Filipino.

$4 \quad$ The writing of this study resonates with what Van Maanen (1988) calls "confessional ethnography". Confessional ethnography is appropriate because of its heightened sensitivity to a particular set of actors in the field. Traditional ethnography highlights the experience of the ethnographer in the field and writing is made from the perspective of the researcher. I will deviate from traditional ethnography and instead write "confessions" from the perspective of officers. For this study, the jail officers would be the actors of interest. As I demystify the profession of jail work and appropriate its human aspects - how the human, the officer, through his or her emotions actively respond to other actors and the objective conditions present in the jail environment. I kept in mind that this study is not a dramatic revelation or exposé of lives. Rather, the writing will try to closely convey, "what actually happens" on the ground (GLASER; STRAUSS, 1967) from the officers' perspective; to express their bouts of doubt, dilemmas, and realizations as they go about their daily duties. While I invited critical assessment from the officers, I am sensitive that they are straddling between personal and occupational lines. I gave utmost consideration to the fact that their participation and my interpretation of the findings may provoke anxieties, cause interpersonal conflicts, and even affect their career. As precaution, I phrased questions in a way that assures officers that I am not looking for a "whistleblower" (WESTMARLAND, 2001Lor trying to find faults and fissures in the setting. I presented the study to a pool of potential interlocutor-officers through a consultative meeting. Each interaction ended with a debriefing session. And at the end of research writing, I presented the findings to the officers in a "validation presentation" which provided the venue to raise any questions and the opportunity for collaboration in analyzing the findings.

This study closely followed research protocols on ethics (AMERICAN SOCIOLOGICAL ASSOCIATION, 1997; INTERNATIONAL SOCIOLOGICAL ASSOCIATION, 2001), namely: anonymity, confidentiality, full disclosure, and beneficence. Permits to conduct the research were secured from the headquarters of the BJMP then endorsed to the city jail warden. Prior to the conduct of the "main data gathering stage", results of the preliminary study were presented to the pool of potential respondents and higher-ups of the BJMP. Letters of invitation with information sheets containing the research questions, objectives, potential risks, and intended benefits were then sent out individually to potential respondents. All respondents came forward voluntarily. Participant information sheets are again distributed and explained prior to each interview and FGD session. The jail and names of the officers have been anonymized. Finally, I guaranteed my interlocutors of the study's belated publication to further protect them from identification. As of June 2021, most officers who participated in this study were no longer part of the facility rendered as site of study. All classified jail records have now been destroyed. 
Furthermore, I was also sensitive to my position as a female outsider in a highly masculinized closed setting (NARIO-LOPEZ, 2018). Among the study's primary contributions is the examination of emotional labor in peculiar working conditions. This study employed the constructivist paradigm to equally account for the multiplicity of realities in a specific social setting (DENZIN; LINCOLN, 2000): a city jail in one of Manila's densest cities. During the formal interviews and focused group discussions (2016-2017), all my interlocutors had rendered two to 22 years of service and were assigned to various parts of the country. The diversity of their experiences offered a spectrum of viewpoints, which validated and contributed to the construction of their collective reality (KITZINGER, 1994). Field notes, photos, transcripts, and official jail records were categorized thematically, manually coded. Information, then organized according to the logic of analysis that best responds to the research questions and objectives.

\section{LITERATURE ON PRISON SOCIOLOGY AND THE PHILIPPINE CARCERAL CONTEXT}

Delving into prison sociology is essential for three reasons: first, to understand the jail as a social space; second, to understand how jail conditions affect daily interactions; third, to provide a localized survey on the qualities and uncertainties that Philippine jails and prisons share. Since Sykes (1958) and Goffman (1959), more scholars framed prisons as social spaces that can structure identities and facilitate/encumber social relations. Initially, however, attention to prison staff only focused on officers' custodial role performance (BOSWORTH, 1999; STOHR; HEMMENS; KIFER; SCHOELER, 2000). Subsequent studies discussed institutional aspects of prison administration and its consequences to job satisfaction (GRIFFIN; HOGAN; LAMBERT, 2012; HOGAN; LAMBERT; JENKINS; WAMBOLD, 2006; LAMBERT; PAOLINE, 2012), job output (HOGAN; LAMBERT; GRIFFIN, 2013), and turnover (HECHANOVA, 2011; LEIP; STINCHCOMB, 2013). A finding which resonated most in this study is the assertion that prison physical spaces and organizational climates have immense influence on quality of work (LAWLER, 1999; LAMBERT; HOGAN; JIANG, 2008), such that poor facilities beget negative organizational climates that act as tonic for officers to readily use force (GRIFFIN, 1999). This gap in the literature pushed scholars to bravely ask how to make prisons better (LEIBLING; ARNOLD, 2004; CREWE, 2009; LIEBLING, 2011; DARKE, 2013) and scrutinize the social aspects that work beneath institutional structures. Studies raised awareness on the moral performance of prisons (LEIBLING; ARNOLD, 2004), fought for ethical canons of incarceration delivery, and held prisons accountable (CULLEN; JONSON; ECK, 2012) for inmate reoffending. Liebling (2000; 2011) and Liebling and Arnold (2004) considered the correctional staff as fundamental in improving prison cultures and delivering the rehabilitative agenda. But how is it possible for a penal system to ethically provide incarceration amidst inferior living conditions?

In Philippine literature, the interest in gangs (mgapangkat) is apparent in early empirical pieces. Ashburn (1965) and Nicolas (1988) for example, both discussed their destructiveness. Later, interest expanded on aspects of Philippine carceral realities that are also depicted in popular media pieces: overcrowding in slum-like vicinities; sluggish justice processes; high incidence of escapes and riots; lack of inmate segregation; little to no implementation of outmoded rehabilitation programs; and as a result, the transformation of minor-case offenders to hardened criminals (BERDIN, 1999; NAVARRETE, 1999). These conditions that seem like inflections of social inequalities outside prison walls make it understandable why many have the impression that gangs reign supreme in the Philippines (NARIO-LOPEZ, 2018). 
Intuitively, as with Crawley's (2004) findings, being continually dispossessed of their authority causes frustration among prison officers. However, Jefferson and Gaborit (2015, p. 87) found that Filipino prison officers do not mind the frustrations even if "[w] orking conditions are not optimal". In this context, "Stress and frustration do not dominate accounts" among the officers (JEFFERSON; GABORIT, 2015, p. 78). They cope by "focusing on getting the job done" (JEFFERSON; GABORIT, 2015, p. 78) and by taking stock on the honor they receive from the public. It came to me as a surprise that in my exploratory phase of research, I found my interlocutors' narratives consistent with Crawley's (2004) and not with Jefferson and Gaborit's findings despite sharing contexts. While officers in my study also focused on accomplishing tasks and performing duties, they expressed profound annoyances and hardships. The officers said that eliminating obstructions "to get the job done" is top priority, such as impoverished jail conditions and gang presence. Moreover, they also do not feel that they are highly regarded by the public despite knowing that they have honorable jobs. I was fascinated by the disagreement between Jefferson and Gaborit's and my initial findings, and I view this as a mystery that needs to be solved.

I realized the need to delve deeper into Philippine jail officers' working realities to comprehend why some feel frustrated and some do not. By employing the emotion management perspective, I zoom in to the dynamics of how officers come into terms with limiting, maneuvering, and controlling personal emotions for institutional purposes (HOCHSCHILD, 1979; 1983). But before elaborating on the emotion management framework, I will discuss the sociology of emotions to restate the necessity of studying human feelings and to define this study's theoretical parameters.

\section{THEORETICAL FRAMEWORK}

\section{THE SOCIAL SIGNIFICANCE OF FEELINGS}

Four decades since its birth, the sociology of emotions continues to advance and secure its place in general sociological perspective (THOITS, 1989). Albeit late (BERICAT, 2012), the field carried with it two important tenets in the study of social life: first, affective states are essential aspects of interactions, relations, organizations, systems, structures, processes, and phenomena in all human group life (RETZINGER, 1991; SCHERVISH; HALNON; HALNON, 1996; BEREZIN, 2009; DEMERTZIS, 2013; GROSSI, 2015), meaning the social has an emotional nature; and second, as its corollary, all human emotions are also social - feelings are socially prompted, expressed, and created (BARBALET, 2009; BERICAT, 2005; 2016; BURKITT, 2002; CHARMAZ; MILLIGAN, 2006; JAKOBY, 2012; KEMPER, 1987; 1987; KÖVECSES, 1990; LEWIS; WEIGERT, 1985).

The field has three distinguished pioneers: Thomas Scheff, Theodore Kemper, and Arlie Hochschild (BERICAT, 2016). Scheff (1977) is among the first sociologists who dared to meddle with emotions. He posits those social rituals form a cathartic effect among individuals, and affective unity with group members arise after sharing a common experience. Kemper (1978) is recognized for investigating two universal elements of social interaction, status and power. He theorized that the kind of emotion interaction depends on the power relations between actors. This research takes most from Hochschild, whose concept of emotion management (1975) explained how feelings are kept privately, altered in display, or completely transformed to conform to the emotion norms of a culture. In Emotion Work, Feeling Rules, and Social Structure (1979), Hochschild expanded the use of feeling rules to explain how cultures define acceptable norms of feeling toward objects, people, and events. In The Managed Heart (1983), she deepened the use of these terms by use of emotional 
labor to explain how feelings are commodified in jobs especially in the service industry, which oblige workers to manage emotions to carry out corporate goals.

\section{DEFINING EMOTIONS}

Emotions are ceaseless human experiences but still appear to be very obscure. Defining emotions in the vernacular (AVERILL, 1980; FRIJDA; MARKAM; SATO; WIERS, 1995) is inadequate (GORDON, 1981; THOITS, 1984; FRIJDA, 1988) for social scientists as they must be precise in description and distinctions must be perceptible. In sociology, emotions occur when four components are present: (a) appraisals of a situational stimulus; (b) changes in physiological sensations; (c) the free or inhibited display of expressive gestures; and (d) cultural label/s applicable to the specific assemblages of the first three components. For emotional experience to be recognized, all four components are necessary (THOITS, 1989). But Scherer (2005) posits that the presence/absence of these elements does not sufficiently resolve the notorious problem of defining emotions from a social-psychological perspective. To resolve this, sociologists attempted to differentiate concepts used interchangeably with emotion. Among various terms, feeling is most interchangeably used with emotion. Feelings and emotions are both regarded as identity enactments (DENZIN, 1984) and people express them according to one's role in a social situation (STRYKER, 1987). Thoits (1989) later delineated feelings as less specific emotional states; and emotions as feelings that have been already socially processed and given meaning. In this sense, feelings are motivators of socially induced action. When expressed or performed, feelings become socially identifiable emotions (KEMPER, 1987; 1990). In this research, the terms emotion and feeling are also used interchangeably. As with Hochschild (1979; 1983), this interchangeability (a) acknowledges that the person consciously recognized the affective phenomenon being spoken of (saloobin, internal feelings or hayag, expressed emotions); and (b) limits the scope of this study from meddling with moods, which are less tied to social situations; and from sentiments, which are bound to past (ala-ala or memory) appraisals of events and relationships rather than reactions to social situations, systems, and structures (THOITS, 1989).

\section{EMOTIONAL LABOR: FROM SOCIAL ALLIANCES TO MUNDANE VIOLENCE?}

The innocence of emotions (PIWONI, 2020) has lasting appeal for people trying to appreciate their feelings. Often, we forget that emotions are produced by structures of interaction and cultural frames in which they are talked about and understood (HOCHSCHILD, 1979; 1983; LUTZ; ABU-LUGHOD, 1990; KUSENBACH; LOSEKE, 2013)._Emotions can be identified into three types of social emotions (BERICAT, 2012): (a) interactional emotions, which include the affective dispositions, emotional states, and emotional processes in the social arrangement; (b) group and collective emotions, those that individuals experience by being a member of a social unit; and (c) emotional climates, which are the transient emotional states shared in a specific social unit.

In understanding social emotions, it is important to note that agreement to feeling norms, responsiveness to group emotions, and surrender to affective climates can be seen as the strongest indicator of group integration, solidarity (DURKHEIM, 1995), and (intergroup) alliances

$5 \quad$ While this study acknowledges Theodosius' (2006) argument that there are both conscious and unconscious emotions, I have no training in Psychology to identify, examine, and analyze unconscious and subconscious emotions. These "unconscious emotions" are instead analyzed in terms of how it may have surfaced or permeated emotion management efforts thereby presenting itself in interactions. I asked interlocutors to "look back" and reflect (saloobin, internal feeling) if there was anything that they would have changed in the moment of interaction or affective experience. 
(PÉREZ, 2015). In these respects, emotions are used by power holders to ensure conformity (MOON, 2013). Having the same emotions indicate a shared morality (SHILLING; MELLOR, 1998). This Durkheimian take on emotions within solidarity puts into perspective how feelings are useful channels and worthwhile ends for social order, and it would be fascinating to know how this plays out in everyday realities in an atypical setting such as the jail and among officers who are rarely given attention when we speak of conditions in penal facilities.

To further the nuances of how emotion binds people and is regulated within groups or cultures, this study will utilize Hochschild's emotion management framework (1979; 1983). Hochschild argues that emotion management is based on important emotion norms that determine what feelings are acceptable to be experienced by; and to whom and how these emotions can be expressed. In specific exchanges, emotion norms are expressed in digestible forms called feeling rules (HOCHSCHILD, 1979; 1983), which are learned and exercised via formal education/training or through informal social channels such as socialization or transference.

Nearly all jobs require some form of emotion management. We also practice it in our personal lives (DITTON, 1980). Emotional management is relevant in the social order and in the continuity of social relations. In the literature, the selection of emotion management strategies varies across the workplace's organizational features and employee's personal characteristics. Broadly, workers employ two types of emotion management strategies namely: (a) behavioral strategies and (b) cognitive strategies. Behavioral strategies correspond to Hochschild's concept of surface acting, which depicts the processes of modifying bodily expressions to appear like what is demanded by the emotion norm. Surface acting can be performed by changing bodily gestures through changes in bursts of energy, smile, or language. At work, surface acting is usually performed to suppress negative responses (DIEFENDORFF; RICHARD; YANG, 2008) and distress (BROTHERIDGE; GRANDEY, 2002). Cognitive strategies are identified with Hochschild's deep acting, which depicts the profound process of how raw emotions are transformed to the mandates of the emotion norm. An employee's mastery and ease of deep acting are positively correlated to factors such as number of years on service (GRANDEY, 2000) and quality of time spent interacting with clients (BROTHERIDGE; LEE, 2003).

Taking from the Goffmanian tradition (1971), emotion norms are relevant in work contexts because it systematizes emotions in interactions according to organizational customs of co-mingling. As an actor in the setting, the individual forms social patterns of feelings and expressions, actively negotiates courses of action, reconciles discrepancies, and confronts situations. To avoid troubles, co-actors must share a definition of the situation and react according to expectations. When all interaction rules are satisfied within and between groups, public order is achieved. However, when disruptions occur, actors renegotiate and determine whether sanctions should be invoked from the relational order (TAVORY, 2020). Individuals are reminded or reprimanded for not acting or feeling a particular way, which has disrupted group order.

But for Hochschild, thoughtful attention must be given when concerns on public order are obscured for organizational identities and purposes, because each moment of social contact have lasting effects in the individual's public and private life (BOLTON, 2005; SISLEY; SMOLLAN, 2012; LIN; TSAI; LIN; CHEN, 2014). Hochschild (1983) criticized industries for imposing emotion management on its workers and aligning feelings for pay, which she called emotional labor. Emotional labor is extrinsic and problematic because emotions are commodified (COSSETTE, 2009). It also violates the feeling self because it limits, interferes, and fabricates human emotion (HOCHSCHILD, 1983). 
To push further earlier findings on the lack of emotional autonomy among individuals, I also ask whether the subjection to emotional labor could be rendered as a form of mundane violence. The concept of mundane violence depicts forms of coercion and subjugation in everyday, normalized, and accepted (SHAHANI, 2003; THOMAS, 2017) practices. Mundane or everyday violence are not necessarily observable actions against persons (such as verbal or physical aggression) but are inflictions subtle enough to be rationalized and excuse perpetuating systems from implication. Mundane violence is entrenched in ideas, systems, and relations that are normalized, reified, and founded on structural and systemic inequalities embodied in norms, mores, and persons.

Mundane violence are the micro manifestations of larger systematic oppression (e.g., economic, social, and political) wherein groups in positions of authority (consciously or unconsciously) subject weaker groups to forms of aggression and agony. Subjugation of weaker members of the group are naturalized to make resistance undesirable (THOMAS, 2017) while celebrating submission and temperance. In such an arrangement, while victims may agonize over the hardships they suffer from these invisible aggressions, they may be unconscious and unable to detect that they have already become willing victims as they too have already accepted (and defended) it as a constitutive aspect of life. However, while most of the literature on structural violence focuses on its effects on the marginalized, it is important to note that this oppression being systemic in nature affects all members of the social strata. Through socialization and transference, the "other side" of the strata are also forced to conform to the ideals of the prevailing system to survive (KLEINMAN, 2000). For example, heteronormative society socializes boys to "act like men" to carry-on patriarchy and a capitalist society rewards the capitalists to encourage further accumulation of more profit. Similarly, in this study, I ask how jail officers who are agents of social control are socialized on how to handle emotions and in turn become tools of oppression as previous studies suggested (O'DONNELL; EDGAR, 1998; EDGAR; O'DONNELL; MARTIN, 2003). Mundane violence circumvents amongst us. Because mundane violence need not come in spectacular forms, crude force, or tactless words, there should be wariness toward emotional labor.

In prison settings, all forms of violence are powerful means to redefine and renegotiate relationships among inmates and inmates with staff (SCOTT, 2006; MARTIN; JEFFERSON, 2019; EDGAR; O'DONNELL; MARTIN, 2012). Specifically, mundane procedures of violence in prison settings are embedded in the relationality, wherein rituals of subordination are enacted (MARTIN; JEFFERSON, 2019). Marked by rivalry, assertion of identity and status, earlier exploration of mundane violence in prisons reveal how powerful social organization and culture affect the ordinariness of violence in everyday prison life (EDGAR; O'DONNELL; MARTIN, 2003).

While mundane violence in prisons has already been tackled by existing studies, which focused on routine victimization within and between prisoner populations and staff members, what I am interested in is how emotion management dynamics translate to mundane violence that hone working procedures and professional relationships, from a systemic and institutional perspective of jail work. I see mundane violence as a fitting lens to push earlier arguments about how lack of emotion autonomy leads to burnout (BROTHERIDGE; GRANDEY, 2002; NÄRING; BRIËT, 2006; BROUWERS, 2006), low job satisfaction (BROTHERIDGE; LEE, 2002), and poor commitment (LAMBERT; HOGAN; GRIFFIN, 2007). Interrogating emotional labor alongside mundane violence is relevant because both concepts render visible social control. Examining emotional labor from the perspective of mundane violence is moreover beneficial to enrich acuities in identifying how banal practices' vehement tendencies are veiled in common interactions, relations, and even celebrated in traditions. 


\section{RESULTS}

\section{EMOTION MANAGEMENT IN THE PHILIPPINE CARCERAL CONTEXT}

The site of study is a city jail located in Metro Manila operated by the BJMP. The facility, which was only a courtyard situated at the back of a police precinct, was never renovated for carceral purposes. Its walls are only 10 meters high, non-compliant to the building code, and unlikely to withstand calamities. With more persons committed than released, 12 detainees share a lungga (box-like space). VIPs (very important prisoners) can rent a kubol (bunk) for a small fee. It is in its many crevices that contraband trade and weapon-making thrive.

The BJMP Operations Manual (2015) sets the standard officer-detainee ratio to 1:7. As of the first quarter of 2018, the city jail operates at an officer-detainee ratio of $1: 80 .{ }^{6}$ However, the figure does not accurately depict daily jail operations as the workforce is further divided into four shifts, leaving only five officers manning the gates. Four are assigned at the towers, and only two officers rove around the courtyard and the dorms, while others attend to administrative duties. A typical officer works 48-60 hours per week, mostly spent in jail premises and in close contact with detainees. Officers from the provinces "stay-in" and only go home every few months. However, since the COVID-19 pandemic erupted in March 2020, all officers had to go on-duty for 28 days straight, wherein the first 14 days is dedicated for quarantine. An officer who has specialized duties in another city jail even stayed for 15 months straight. The precarity of Philippine penal facilities is indeed heightened by the pandemic, forcing the bureau to find measures before this epidemiological "landmine" explodes and wreak havoc in overpopulated facilities and slum areas that usually surround them (NARIO-LOPEZ quoted in PATAG, 2021).

To prepare potential officers and refresh seasoned officers for protracted work hours, the National Jail Management and Penology Training Institute (NJMPTI) offers six types of courses given at different career points. This is where they imbibe "the most intricate cognitive knowledge, skills, and proper attitude required in performing the duties and responsibilities" of an officer (NJMPTI, 2015). Here, officers prepare for the occupational culture, learning how things are done here. The occupational culture in Philippine jail work is circumscribed by its institutional mandates (BJMP, 2015) and translated into its two main job deliverables: protective service and welfare care. In their role as protective workers, officers ensure the security and safety of PDLs. Within facilities, they try to maintain order, implement regulations, and enforce court issuances. This role expects officers to be unyielding. Likewise, the job entails welfare care because of their responsibility to provide "safekeeping and development" (BJMP, 2015) for PDLs in the form of rehabilitation programs. As care workers, officers need calm temperaments, openness, and empathy (AULENBACHER; LUTZ; RIEGRAF, 2018). Officers need to "toughen up" to maintain an image of credibility and power. Raw personal emotions cannot be expressed haphazardly. Emotionality is discouraged; display of positive feelings should be regulated, and negative emotions should be suppressed. Specifically, embarrassment, shame, and anger are unfitting for an officer. Officers use emotion management strategies to transform feelings into normative ones.

From the focus group discussions, I was able to identify the surface acting strategies that officers practice: (a) smiling to set a pleasant mood; (b) joking around (biruan) to lighten or ease frustrations; (c) downplaying all emotions (emosyon lang iyan); (d) indirect communication through 
ambiguity (pasaring). Deep acting techniques used by officers focused on the cognitive reframing of the situation, such as (a) invalidation of one's own opinions or feelings; (b) rationalizing discomfort as just a symptom of physical exhaustion; (c) justification of their emotional struggle as something they must get used to; and (d) valuing resilience as part of character-building.

\subsection{ARGUMENT 1:}

\section{PAGLULUGAR SA SARILI - RANK AS EMOTIONAL CAPITAL AND FIXED POINT IN EMOTION NAVIGATION}

City jail officers deploy emotions based on calculations of intersubjective social positions. In this section, I introduce evidences of howe motion management can become a social practice that is not only interactive (HOCHSCHILD, 1983) and relational (CRAWLEY, 2004), but also intersubjective (ZAHAVI; OVERGAARD, 2013). In the city jail, intersubjectivity is steered by a durable and fixed structural indicator in emotion navigation: the ranking system.

Ranks in BJMP represent wisdom, credibility, and achievement. They have heavy symbolic value. Senior officers are esteemed because their position represents a summative range of experiences, wherein the experiences are essentialized as hardships (mgapinagdaanan) and are therefore praised. Ranks define the officers' lugar (place, position) in the jail system. It dictates how one must be alluded to, conversed with, and treated. Through acculturation, lower-ranking officers learn emotion management routes by considering the honor stripes worn by personnel they Interact with. Young officers are socialized into conventions of rank via positive reinforcement.

Rank as a fixed point in emotion navigation is evident in the nuancing of display rules. Knowing their place marks an officer's limitations (doon ka lang) in expressing certain degrees of positive and/or negative emotions. Toward senior officers, officers try to give-off poised dispositions for agreeability. Toward co-ranks, officers maintain a consistent flow of positive emotions to sustain harmony. Toward PDLs, seen as the lowest social position in the context, officers need to perform authority. Officers said it was easy to manage their emotions in this regard, because they always remind themselves: huwagkangtataas pa! (never cross the line). They are always expected to remain modest (mapagkumbaba).

Kemper $(1978 ; 1987)$ and Hochschild's $(1979 ; 1983)$ analysis on the structural components of emotion help us understand the intersubjectivity of emotional labor based on rank. Common in their analysis is the regard for power and status as emotion-solicitors. Across the power strata, emotional experiences vary. In the jail, negative feelings are often directed downward while positive feelings could only be directed upward (LIVELY; POWELL, 2006). This is exemplified by experiences of new officers, wherein their seniors unreservedly expressed disdain. These new officers, in turn, are expected to express humility and promise that the cause of disappointment will not happen again. It is never acceptable for a lower ranking officer to express disagreement or any other negative emotion to a senior. As rank clearly defines emotion expectations, it can be argued that one's social position can earn exemptions from emotional labor. Status garners compliance voluntarily, as officers have learned to value subservience as part of Filipino tradition. Power, meanwhile, is usually solicited from detainees in the form of influence, coercion, threat, and fear.

Crawley (2013) posited that every organization has varying emotion zones, or spaces within the workplace that are used according to the type and degree of socially-acceptable forms of emotion (HEARN, 1993). For jail officers, however, these emotion zones are not limited to physical spaces. Emotional freedoms are carried by the person who owns the rank and possesses currencies for autonomy in self-expression. For a lower-ranking officer, sensitivity to others' emotion freedom is a 
delegated skill known as paglulugar sa sarili (knowing your place). As with other norms, non-compliance receives sanctions. For example, an officer who dares to express antagonism comes-off as ma-ere (arrogant) and called-out for being walasalugar (not in-place). Emotion freedom is formally used by the bureaucracy to align interpretations of emotive experiences to the imposition of affective structures to microsocial order (VON SCHEVE, 2012).

The practice of paglulugar sa sarili is also interesting from the viewpoint of gender analysis. Jail officers are taught how to display masculine self-comportment. However, when interacting with seniors, their relative position toward higher ranks mandates rendering of feminized traits, such as docility, patience, and servitude. One officer said, when I asked if tough dispositions seem to conflict with traits that need to be displayed to signal subservience to rank, he simply said it is just how it is (ganun talaga iyon) - normalizing and reifying reverence to rank. When I asked if the expectation to submit to higher authorities emasculates him, the officer said: hindi iyon nakakalalaki (it is not emasculating) and added that deference to rank is cogent to be a good officer (dapat marunong ka rumespeto lalo na kung uniformed, you need to learn how to respect especially uniformed personnel).

Cottingham (2016) offers a valuable take in analyzing these findings about paglulugar sa sarili (finding your rightful place). Cottingham suggested that it would be more productive if we treat emotion management separate from emotional capital. By seeing that emotion management as a social process and social capital as a resource that directly links "macro structures and micro-resources" (COTTINGHAM, 2016), we can understand why senior officers enjoy emotional freedom. As with Cottingham's (2016) findings, emotional capital in the context of the bureau's occupational culture is not gendered. All officers value and pursue emotional capital, with heavy reliance on the longstanding tradition for rank objectification. However, in the context of the city jail, I view rank as emotional capital that marks eligibility to defer from emotion management and not necessarily the competence to better manage emotions (COTTINGHAM, 2016). Based on the narratives of officers, senior officers have the emotional capital that privileges them to haphazardly express emotions because respect (and amenability) is due no matter what emotions they display. And indeed, officers shared that there are no guarantees that higher ranks are better managers of affective states.

As emotional capital, rank determines an officer's habitus and steers affective dispositions. As with medals that symbolize it, rank is robust. Rank as emotional capitalist used in the city jail as a trans-situational resource that is accumulated, embodied, and activated as power and privilege in interactions. Though the ranking system is permeable through promotions, intersubjective appreciation across rank is not negotiable in the occupational culture of the bureau.

\subsection{ARGUMENT 2: EMOTION REGIMES - APPRAISALS OF SISTEMA AND KALAKARAN}

Previously, I discussed how officers arrive at a sense of place (paglulugar sa sarili) after following emotion management routes based on intersubjectivities. Paglulugar sa sarili underpins the acceptance of three types of predicaments that officers had accepted as perpetual facts of jail life. First, officers accept that despite the need to strive for universal jail standards, such as the United Nations Nelson Mandela Rules (UN GENERAL ASSEMBLY, 2015), scarcities in jail come with restrictions and consequences. To them, this does not mean lowering benchmarks, but a matter of pagiging ma-abilidad or having competence that is marked with ingenuity and persistence to confront limitations strategically. Second, officers see themselves as bearers of justice who must discipline humanely by being firm yet understanding (matigas pero nakakaintindi). Among the narratives, a very strong source of deep acting technique are mantras depicting a moralization of emotional labor as means to rehabilitate detainees despite frustrating jail facilities and personal 
emotion obstacles. The two predicaments relate to the third, wherein officers can be negotiated (napapakiusapan) within terms of following custodial mandates, as long as they see it as beneficial to detainees' living conditions and rehabilitation (e.g., giving permits for small appliances to better living conditions for PDL).

Regimes depict routines, associations, operational policies, and access to services within facilities. It is largely determined by the character of leadership and political climate among prison staff. In the site of the study, these regimes are sistema and kalakaran. In Filipino colloquial language, sistema and kalakaran are denotatively synonymous with each other. Both refer to the character and process of how things are "made to work" (nagagawan ng paraan) despite predicaments. In jail life, however, these are connotatively nuanced from each other. Each regime has differences in qualifying practices according to its selective ethical qualities by which the labeling of a practice (whether it is a sistema or kalakaran) is based.

Sistema. Officers depicted sistema (system) as routine practices that are not exactly "by the book", but also not entirely detrimental. Sistema is a satisfactory way to get something done (pwede $n a)$. Though substandard in outcomes, Sistema is considered as a form of "social innovation" because it carries the bureau's good intentions, and gets the job done despite limitations. It is tantamount to their "best efforts." In the higher ranks, the warden and unit heads recognize the value of sistema as part of their humanitarian and efficiency credo (CRAWLEY, 2004). Sistema is seen in how officers deploy pangkat (gangs) in the sustenance of jail provisions (allowing entry of food, medicines, and visitors for psycho-social and moral support of PDL) and in supplementing manpower via the employment of jail trustees and other duty bearers (nanunungkulan). Sistema is compassionate, yet some would question that its brutal pragmatism causes backlash to jail governance.

Kalakaran. While sistema is widely accepted, there are also personnel who exploit these practices. In jail language, they are called sistemador. A sistemador is an officer who, because of their position to lodge a sistema, has turned into accomplices for detainees' entry of non-essential appliances, mobile gadgets, prostitutes, and contrabands for pay (padulas, meaning bribe). Emotional capital is used to mobilize individual interest (ERICKSON; STACEY, 2013). This system is called kalakaran, derived from the Filipino word lakad (to walk). In colloquial use, if you are nagpapalakad (asking someone to "walk" or do something for you), you capitalize on patrimonial relationships to get ahead. Pagpapalakad is a form of patrimonialism, considered a longtime flaw in Filipino relationships and a major cause of corrosion in governance (MCCOY, 2009). May mgaganyantalaganggalawan (these maneuvers are a part of reality), as one officer explained — verbalizing its reification. Sistemadors had lost sight of the good intentions of sistema, shared another staff member. Kalakaran depicts a mode of operation that is largely meandering, corrupt, and undeniably unethical.

Despite glaring violations, kalakaran continues to exist for three reasons. First, some justify kalakaran based on claims of reciprocity in relationships - a part of getting along (SYKES, 1958) - since some detainees deserve the incentive for taking part in the efficiency credo (CRAWLEY, 2004). Second, a very straightforward reason, some officers accept pampadulas (bribery) ${ }^{7}$ for extra income. And lastly, one senior officer bravely revealed that some participate in kalakaran for the nostalgia it brings. The unit head even explained the many ways to do kalakaran prevalent decades

$7 \quad$ In Filipino everyday language, means lubricant. Lubricant is needed to loosen-up things; so, to loosen up stringent rules, bribery as pampadulas is needed. 
ago. It has a feel of tradition, and sistemadors believe that in kalakaran, they become a part of the elite.

Notwithstanding a clear clash of concessions between those who rationalize sistema and excuse kalakaran, diplomacy is present in the city jail. I noticed that co-ranking officers never mentioned names despite the sensitivity of this finding. Boundaries are maintained and there is respect for each other's working personality. In times of disagreement, officers arrive at paglulugar sa sarili by maintaining distance and avoiding confrontation to show respect toward their differences. It is more complicated, however, when a boss is involved in kalakaran. Having a sistemador boss is disappointing because officers believe that their seniors should have integrity and honor. Generally, junior officers react to kalakaran in leadership in the following ways: (1) some feel a sense of denial that questionable officials could exist; (2) they only deal with their bosses out of respect for the position they are holding (and not the person) due to loss of faith in the leadership; and (3) they feel it was harder for them to be "alright" with sistemador leaders than sistemador peers. There is a common fear that when a leader gets beholden by a kalakaran, everybody else down the bureaucracy line needs to fall from grace, engage in corruption, or at the very least channel evil's banality (ARENDT, 1963).

Officers who experienced meandering regimes shared that they had to process raw emotions intensely and with a wider variety of behavioral and cognitive strategies. Some anecdotes include officers "keeping their head down" or "looking the other way" when interacting face-to-face with such bosses. Some cannot help but bring home stories of grief about bosses who made them accomplish unreasonable tasks and defeat for having to work for a circuitous regime. Officers found it harder to build relationships with someone they do not trust but need to obey.

In the city jail, kalakaran - who runs it, and who else is involved - is regrettably not open to public conversations, even among senior officers. Dominant in the narratives, however, is there markable finding that officers take having an intuitive "bad feeling" (masama ang kutob) toward things, people, and events as clues to morality. Officers are more open to discussing this. When someone says masama ang kutob ko diyan (I have a bad feeling about that), it means that the officer does not want to be involved with it or must be prepared to deal with whatever it is. This confirms Katriel's (2015) earlier work on the link of morality to feeling.

In terms of group solidarity, circuitous regimes negatively affected the mood and solidarity within the organization such that they found themselves into factions and even wanting to leave service. Despite this, conviviality between inmates and staff remains essential in prison survival (CRAWLEY, 2004). And while Darke (2018) notes the importance of inmate solidarity to convey stakes to management, the officers in this study point that loyalty between uniformed personnel is also relevant in maintaining command.

Whatever the type of regime, officers have to and do willingly subvert their emotions to abide by principles of professionalism. From the narratives of officers, they see professionalism as a contribution (ambag) to the institutional goals of the bureau.

\subsection{ARGUMENT 3:"PROPESYONALISMO"AS EMOTION CULTURE}

Jail work culture is different from other occupations (SYMKOVYCH, 2018), because entering the service, new recruits must immediately cope with "culture shock" (CRAWLEY, 2004). Shocks aredue to fear of being bristled by "dangerous criminals," be rung down by boisterous gang leaders, and being bombarded with riots and escapes (KALINICH; PITCHER, 1984). Officers confirm these earlier findings, adding that levels of shock depend on the type of prison regime initially 
encountered. They recount being defamed, terrorized, and designated to shoddier facilities as chastisement by their bosses. They said that despotic regimes may confuse, compel, or shackle even an old-timer.

Acculturating to unpredictable emotion climates is complex and exasperating. Officers experience a mix of panic, self-doubt, and anxiety whenever there are changes in assignments and leadership. Thus, officers put a premium to their emotion culture maxim-propesyonalismo (professionalism). To be professional means that they need to unfailingly observe the following practices integrative to jail service: (a) preparation; (b) letting go of civilian mentality; (c) following orders; (d) following due process; and (e) tenacity.

Prepare yourself. Self-preparation (Ihanda mo ang iyong sarili.) helps officers in two ways: (a) for juniors, in acculturating to the "shock" of jail life; and (b) for seniors, strengthening their service throughout their career. For young officers, being prepared means knowing what is expected from them. For example, Officer K shared that during her early years, her boss suddenly scolded her upon seeing that she made herself a cup of coffee: Oh! Bakit hindi mo akokinuhanan? Sipain kita diyan eh! (Oh! Why didn't you make a cup for me too?! I might kick you!). Stunned by her boss' harsh language, she almost cried. Yet a few days later, Officer $\mathrm{K}$ realized that the incident was her fault because she did not carry what was expected of her. Another officer was redesignated to a jail for no apparent reason and upon leaving the old facility, a gossip spread that she allegedly impregnated a female PDL, being a lesbian. Now looking back, she said that she now just laughs it off because the gossip died down any way, not minding that what happened is actually a form of bigotry and discrimination. Others shared similar stories of distress as new recruits, but they eventually got accustomed to it as natural demands of jail work, namely: (a) developing patience to understand that their bosses' treatment must not be taken personally; (b) having perceptiveness to detect deception from devious detainees; (c) hiding signs of emotionality to avoid being the butt of jokes and the target of confrontations. For senior officers, being prepared means having the right mindset. Preparation develops their abilidad (competence) to lead and make sound decisions for their unit. Preparation, according to Officer A, begins even before they enter the gates. It starts as they carefully iron their blue-gray uniforms, shine their badges, and top their caps on their heads. Preparation starts with a ritual to gather clarity of thought. The warden even shared that he developed an instinct for things about to happen in the facility by honing his mindset (para bang kalkulado mo na, it is like you can already calculate what is about to happen).

"Let go of civilian mentality". Donning uniforms that carry ranks, officers consider themselves as "paramilitary" ${ }^{8}$ Generally, they affiliate themselves with other uniformed public servants, such as the military, police, and firemen. They see themselves as magkakabaro (of the same attire, dress) because they have similar features in job training, organizational structures and goals, lifestyles, and beliefs. They have a shared sense of identity in upholding their duties as fundamental in an orderly and peaceful society. For them, letting go of "civilian mentality" is essential in accomplishing their responsibilities. This means officers must always be disciplined to serve as exemplar protectors of the law. Being disciplined means being in command — of yourself, your life, and your mundane inklings (kababawan), which are seen as products of emotions.

$8 \quad$ BJMP's origins and present composition take from the Philippine National Police's martial quality. Many high-ranking officials take pride in this because they were trained in the national police academy. 
Officers say that unlike civilians who are "free to express" how they feel, uniformed personnel must be in control of traits unbecoming of their uniform. They explained that for common folk this may seem like curbing liberties. But to them, this is strength, because it enables them to distinguish feelings from principles. Feelings and principles are antagonistic forces in uniformed service because they believe that: (a) emotions treat the self as the absolute point of reference in assessing situations, events, or objects; (b) while principles are logically grounded other-centered beliefs that beget beneficial outcomes for many. Thus, officers associate emotionality as a self-centered (solipsistic) attribute, while being principled as other-centered (makatao). The delineation of emotions from principles resonates the longstanding dichotomy between emotionality and rationality in social theory (ILLOUZ; FINKELMAN, 2009). However, officers' rationalizations speak more of collectivist consciousness rather than pragmatic ends - consistent with the premises of SP (ENRIQUEZ, 1976; 1994) about Filipino consciousness and social logics.

Follow orders. Through preparation and acceptance of the demands and eagerness to contribute (ambag) in "uniformed service", it became easier for officers to take orders willingly. However, there are instances when officers experienced the need to follow orders despite their disagreement, such as the case of being led by depraved regimes. Officer A said: "kasi sa bureau, basta sundin mo nalang" (in the bureau, just follow). He added that officers have learned how to separate their professional life from their personal preferences, conveniences, and moralities. They need to accept the order (accept ka lang). This again affirms how officers can have tough but docile dispositions. Even though they feel degrees of repudiation or negation, they still choose to endure the sacrifices (magtiis) over their conveniences. Unwavering obedience to orders is key to professionalism and proves the officers' allegiance to the institution.

Follow due process. Another part of professionalism is the vow to always follow due process. If something is of concern to officers, they cannot simply vent these out informally. Whether these involve their superiors, co-officers, or detainees, concerns should be written down and coursed through bureaucratic channels. Officers see three benefits in pursuing their concerns via formal channels. First, they learn how not to hastily act upon their emotions. The time needed to process complaints allows officers to calm frayed nerves, "be pulled back to rationality" and realize that "hindi pala lahat ng bagay, puro galit" (anger is not always productive). Second, following due process allows officers to regain composure, "para matauhan" (to come back to one's senses, be human or tao again). By being calm, one can hear all sides of the conflict. Through this, they develop a deeper sense of understanding each other's experiences and courses of action become pluralistic. Third, officers find that following due process enables them to be human-centered and compassionate (kasi kailangan makatao), since the deliberative process maintains an outlook of impartiality. This assists the BJMP's long standing goal of "humane safekeeping" (BJMP, 2015). But what happens when the colleague under question is a superior involved in kalakaran? According to the officers, kalakaran does not exist in all jail leaderships. If it does, the officer may file a concern against the immediate boss in question to higher offices, but this runs the risk of being demeaned or formally sanctioned for by passing authority. So, it becomes the common recourse that the aggrieved officer is left to fend for his own, let the time pass, and not file any cases formally.

Tenacity. Officers admittedly describe their workplace as difficult. To them, the only way to survive is to be tenacious. As a senior officer, who has been with BJMP for more than 20 years shared, many had come and gone. Other officers agreed, saying that they are understaffed because many cannot withstand jail conditions and pressures at work. BJMP's low retention rate led to universal understaffing despite unceasing public recruitment efforts. To stay in service, tenacity 
must be practiced in three broad areas of work: (a) in stretching and replenishing patience; (b) in continuing despite the hindrances, challenges, and repeated shocks; (c) in focus and persistence to get the job done.

These five features of professionalism — preparation, letting go of civilian mentality, following orders, following due process, tenacity - allow officers to be in command of their emotions. Emotion labor in jail serves both individual and collective purposes.

\section{DISCUSSION}

In this article, I laid out three arguments as an engagement to Hochschild's emotion management framework and enrichment of Crawley's empirical work. Insights from officers in a Metro Manila city jail demonstrate how the deprived carceral environment shapes the dynamics of feeling modification rules, transactional systems, regimes, and value for emotional labor.

I forwarded three key points in the analysis of findings. First, the process of emotional management is compounded by predicaments on positionality where rank is a fixed navigation point, and each officer is expected to be responsible for paglulugar sa sarili (finding their place). Second, emotion norms are not only determined by the occupational culture's interactional scripts but are also delimited by the officers' agreement to the values impinged in the practices of the regime (sistema or kalakaran). Lastly, officers need to accept any type of regime as public service, wherein professionalism renders emotional labor as an armor in jail life.

Findings of this research show that in the case of jail officers in a Philippine carceral facility plagued with material deprivations and bureaucratic chasms, emotional labor becomes an endowing toolkit by which officers traverse through the difficulties of work while maintaining positive dispositions that furthers the interaction order. Emotional labor is endowing in two respects: first, emotional labor protects social relations by curbing stressors, deescalating stressful situations, and eliminating sources of conflicts; second, emotional labor enables psychological distance, emotional energy efficiency, and confidence in delivering their duties.

The narratives of officers on the perceived endowment of emotional labor reveal a discourse on public service. First, the jail officers share the belief that sacrifices and hardships are inherent in public service. Second, officers endure sacrifices because they see it as an opportunity to earn a dignified living that is also somehow heroic. And third, public service in jail work fulfills nationalist ideals to help develop the country and protect Filipino society. Through professionalism, emotional labor is appreciated as endowments in delivering public service.

Loyal to its attempts to contribute theoretically and methodologically, this research's use of SP divulged the layers and textures of Filipino emotions and feeling management by engaging indigenized terms. The richness and peculiarity of officers' emotive dispositions and experiences are put at the forefront to clarify western theoretical departures. Contrary to existing literature and empirics, jail officers in this study do not feel that emotional labor is detrimental to them. In fact, when asked if they have experienced emotional dissonance after intense and protracted episodes of emotion management, the officers said that they do not.

Further, SP provides sharp insights in analyzing this conclusive finding. Relevant here is SP's suggestion that Filipinos have unique relational platforms and place utmost importance to strong and close interpersonal relationships. First, it is possible that the jail officers see the emotional laboring they do is not a guileless imposition upon their individuality or personhood. The officers already laid claim to their view that managing emotions is their contribution to the bureau's core objectives as an institution that assists in nation building. In such rationalization, enduring emotional labor 
is valued beyond solipsistic suppression of raw personal emotions. Second, because officers feel a sense of community within the uniformed service, they feel less lonely in their emotions for they trust that they are not alone in this. Knowing that what they are upholding is a heritage of strength and camaraderie for public service reenergizes tired spirits. Third, sympathy over others (specifically toward the detainees) also obscures the strains, pressures, and anxiety that their work conditions bring. This analysis of jail officers' emotional labor, through SP, proves further that Filipinos do take collectivist rather than individualist standpoints in assessing social experiences and appreciating affective involvements.

\section{EMOTIONAL LABOR: A PRECURSOR TO MUNDANE VIOLENCE?}

The officers' narratives show how emotional labor can be both threatening and benign; it also has the potential to empower. However, I caution that seeing emotional labor neutrally is double-edged. On one hand, emotional labor as defense allows officers to plow through their jobs and be productive whilst facing many challenges. But on the other hand, emotional labor can be deeply moralized within discourses of public service to the point that officers no longer recognize if it has a toll on their own emotional health. We must assess until when and up to what extent can officers endure such "public service" obligation.

To me, the perversion of emotional labor for institutional goals remains unjustified. Hochschild (2000) asked: "What emotions would we experience if we weren't working ourselves to death?" I agree that emotions should neither be used for profit, for the image of the organization, nor for the glorification of public service. Whenever an entity takes control of what an individual feels and expresses, it is not only the emotion that is taken away from the individual - the individual is also taken away from the emotion. It is not only work that gets dehumanized but the emotion itself. From the narratives of officers, we are affirmed that emotional labor is deeply entrenched jail work culture, applied as a prescript and postscript to individual action, and carried over as personal aspirations.

I fear mundane violence for the jail workers for three reasons. First, it struck me how much the officers alluded to their "paramilitary" training as a pivotal experience for them to willingly submit to rank. Among low-ranking officers, agential capacities seem to be heavily arbitrated by what they learned in training and as they continuously become "better" officers. Emotional labor in the context of jail work in the Philippines deserves attention because, as with mundane violence, its impositions come from social structures, flow through, and can be amplified by actors who (may or may not) unknowingly dispense inequalities to unaware subjects (SHAHANI, 2003; CORCORAN, 2005; THOMAS, 2017). The findings of this study heavily resound Kleinman's (2000) argument that socialization is a decisive tool in hiding nodules of oppression. Second, mundane violence allows hegemonic groups to subject weaker groups by making resistance undesirable (THOMAS, 2017). All officers are deeply socialized to conform and even advocate for, or defend, prevailing bureau "traditions," ideals, and regimes to survive. All aspire for rank. And third, even though channels are made available to them via "due process," reform is kept to a minimum.

These lead me to an overarching fear and worry: I ask whether the officers in my study only value emotional labor because they have unconsciously internalized oppressive conditions and situations as "natural" in public service. I am troubled because I believe that having impoverished conditions, being in the third world, should never be an excuse for controlling human feeling. There should be no suffering in public service. And, even in affluence, we must be wary of contexts where subservience is not only praised but prized because this is where mundane violence thrives. 


\section{RECOMMENDATIONS}

I suggest two trajectories of research to deepen the findings of this study. First, I encourage scholars to refine conceptualizations on the interplay between emotion management and emotional capital to reveal how else social expectations reify social inequalities. Second, I recommend studies to look in to how structural conditions mirror micro-manifestations of systemic oppression. I see these research trajectories fundamental in formulating propositions on how mundane violence can be surfaced further and confronted in bureaucratic settings.

Finally, I recommend administrators and policy makers adopt more critical views and proactive lines of action to alleviate the consequences of destitute carceral conditions. In addition, attention must be given to the ways in which bureau policies and informal cultural expectations/traditions aggravate the demands for officers to succumb to emotional labor. I advocate those resources be made available in the bureau to ensure emotional equanimity and wellbeing of officers. I hope that justice systems finally see the relevance of jail and prison work in the success of rehabilitative goals, beyond manning gates and appeasing riots.

\section{REFERENCES}

AMERICAN SOCIOLOGICAL ASSOCIATION. American Sociological Association Code of Ethics, 1997. Disponível em: https://www.asanet.org/sites/default/files/savvy/images/asa/docs/pdf/CodeofEthics. pdf. Acesso em: 26 jun. 2021.

ARENDT, Hannah. Eichmann in Jerusalem: The Banality of Evil. New York: [s.l.], 1963.

ASHBURN, Franklin. Some Recent Inquiries into the Structure-Function of Conflict Gangs in Manila City Jail. Asian Studies Journal, [s.l.], vol. 3, n. 1, p. 126-144, 1965.

AULENBACHER, Brigitte; LUTZ, Helma; RIEGRAF, Birgit. Introduction: Towards a Global Sociology of Care and Care Work, [s.l.], vol. 55, n. 4, p. 495-502, 2018.

AVERILL, James R. A Constructivist View of Emotion. In: PLUTCHICK, Robert; KELLERMAN, Henry. Emotion: Theory, Research, and Experience. New York: Academic Press, 1980. p. 305-339.

BARBALET, Jack. A Characterization of Trust, and Its Consequences. Theory and Society, [s.l.], vol. 38, n. 4, p. 367-382, 2009.

BERDIN, Reynaldo. The Problem of Jail Congestion in the Bureau of Jail Management and Penology: An Assessment. National Defense College of the Philippines: Quezon City, 1999.

BEREZIN, Mabel. Exploring Emotions and the Economy: New Contributions from Sociological Theory. Theory and Society, [s.l.], vol. 38, n. 4, p. 335-346, 2009.

BERICAT, Eduardo. The Sociology of Emotions: Four Decades of Progress. Current Sociology, [s.l.], vol. 64, n. 3, p. 491-513, 2016.

BERICAT, Eduardo. Emotions. Sociopedia.isa, [s.l.], p. 1-13, 2012. 
La cultura del horror en las sociedadesavanzadas: de la sociedadcentrípeta a la sociedadcentrífuga.

Revista Española de InvestigacionesSociológicas (REIS), [s.l.], vol. 110, n. 1, p. 53-89, 2005.

BOLTON, Sharon. Emotion Management in the Workplace. [s.l.]: Macmillan International Higher Education, 2005.

BOSWORTH, Mary. Engendering Resistance: Agency and Power in Women's Prisons. London: Routledge, 1999.

BROTHERIDGE, Céleste; LEE, Raymond T. Development and Validation of the Emotional Labour Scale. Journal of Occupational and Organizational Psychology, [s.l.], vol. 76, p. 365-379, 2003.

; LEE, Raymond T. Testing a Conservation of Resources Model of the Dynamics of Emotional Labor. Journal of Occupational Health Psychology, [s.l.], vol. 7, n. 1, p. 57, 2002.

; GRANDEY, Alicia A. Emotional Labor and Burnout: Comparing Two Perspectives of "People Work". Journal of Vocational Behavior, [s.l.], vol. 60, n. 1, p. 17-39, 2002.

BUREAU OF JAIL MANAGEMENT AND PENOLOGY (BJMP). BJMP Comprehensive Operations Manual Revised 2015. Quezon City: Department of Interior and Local Government, 2015.

BURKITT, Ian. Complex Emotions: Relations, Feelings and Images in Emotional Experience. In: BARBALET, Jack. Emotions and Sociology. Oxford: Blackwell, 2002. p. 151-167.

BUSTINERA, Jayrex. Reducing the Re-offense Rate of Inmates: A Strategy for the Bureau of Jail Management and Penology-Quezon City Jail, Quezon City. Asian Institute of Management, Makati, 2016.

CHARMAZ, Kathy; MILLIGAN, Melinda J. Grief. In: STETS, Jan; TURNER, Jonathan. Handbook of the Sociology of Emotions. Boston: Springer, 2006. p. 516-543.

CLEMENTE, Jose Antonio. An empirical analysis of research trends in the Philippine Journal of Psychology: Implications for Sikolohiyang Pilipino. Philippine Social Sciences Review, [s.l.], vol. 63, n. 1-33, 2011.

CORCORAN, Mary. Researching Women Political Prisoners in Northern Ireland: Ethnographic Problems. In: SKINNER, Tinner; HESTER, Marianne; MALOS, Ellen. Researching Gender Violence: Feminist Methodology in Action. Oregon: Willan Publishing, 2005. p. 125-145.

COSSETTE, Michel. Role of Organizational Factors on Emotional Labour Strategies. Annual Conferences of the Administrative Science Association of Canada, [s.l.], vol. 30, p. 1-16, 2009.

COTTINGHAM, Marci. Theorizing Emotional Capital. Theory and Society, [s.l.], vol. 45, n. 5, p. 451470, 2016.

CRAWLEY, Elaine. Doing Prison Work. New York: Routledge, 2013.

Emotion and Performance: Prison Officers and the Presentation of Self in Prisons. Punishment \&Society, [s.l.], vol. 6, n. 4, p. 411-427, 2004. 
CRESWELL, John W. Qualitative Inquiry and Research Design: Choosing Among Five Traditions. Thousand Oaks, CA: Sage, 1998.

CREWE, Ben. The Prisoner Society: Power, Adaptation and Social Life in an English Prison. Oxford: Oxford University Press. Oxford: Oxford University Press, 2009.

CULLEN, Francis; JONSON, Cheryl Lero; ECK, John. The Accountable Prison. Journal of Contemporary Criminal Justice, [s.l.], vol. 28, n. 1, p. 77-95, 2012.

CURATO, Nicole. Respondents as Interlocutors: Translating Deliberative Democratic Principles to Qualitative Interviewing Ethics. Qualitative Inquiry, [s.l.], vol. 18, n. 7, p. 571-582, 2012.

DARKE, Sacha. Inmate Governance in Brazilian Prisons. The Howard Journal of Criminal Justice, [s.l.], vol. 52, p. 272-284, 2013.

DARKE, Sacha. Conviviality and Survival: Co-producing Brazilian Prison Order. United Kingdom: Palgrave Macmillan, 2018.

DEMERTZIS, Nicolas (org.). Emotions in Politics: The Affect Dimension in Political Tension. London: Palgrave Macmillan, 2013.

DENZIN, Norman. On Understanding Emotion. San Francisco: Jossey-Bass, 1984.

; LINCOLN, Yvonna S. Handbook of Qualitative Research. Thousand Oaks, CA: Sage, 2000.

DIEFENDORFF, James M; RICHARD, Erin M; YANG, Jixia. Linking Emotion Regulation Strategies to Affective Events and Negative Emotions at Work. Journal of Vocational Behavior, [s.l.], vol. 73, n. 3, p. 498-508, 2008.

DITTON, Jason. The View from Goffman. London: The MacMillan Press, 1980.

DURKHEIM, Émile. The Elementary Forms of Religious Life. New York: Free Press, 1995.

EDGAR, Kimmett; O'DONNELL, Ian; MARTIN, Carol. Prison Violence: Conflict, Power and Victimization. New York: Routledge, 2012.

; O'DONNELL, Ian; MARTIN, Carol. Prison Violence: The Dynamics of Conflict, Fear and Power. Cullompton: Willan Publishing, 2003.

ENRIQUEZ, Virgilio. Pagbabangong-dangal: Indigenous Psychology and Cultural Empowerment. Quezon City: Akademya ng Kultura at Sikolohiyang Pilipino, 1994. 3-18, 1977.

Filipino Psychology in the Third World. Philippine Journal of Psychology, [s.l.], vol. 10, n. 1, p.

. Sikolohiyang Pilipino: Perspektibo at Direksyon (Filipino Psychology: Perspective and Direction). In: ANTONIO, Lilia. Ulat ng Unang PambansangKumperensya sa Sikolohiyang Pilipino. Quezon City: PambansangSamahan sa Sikolohiyang Pilipino, 1976. p. 221-243. 
ERICKSON, Rebecca; STACEY, Clare. Attending to Mind and Body: Engaging the Complexity of Emotion Practice Among Caring Professionals. In: GRANDEY, Alicia; DIEFENDORFF, James; RUPP, Deborah. Organization and Management. Emotional Labor in the 21st Century: Diverse Perspectives on Emotion Regulation at Work. New York: Routledge, 2013. p. 175-196.

FLAM, Helena; KLERES, Jochen (orgs.). Introduction: Methods of Exploring Emotions. London: Routledge, 2015.

FRIJDA, Nico. The Laws of Emotion. American Psychologist, [s.l.], vol. 43, n. 5, p. 349-358, 1988.

; MARKAM, Suprapti; SATO, Kaori; WIERS, Reinout. Emotions and Emotion Words. In: RUSSELL, James A. et al. (ed.). Everyday Conceptions of Emotion: An Introduction to the Psychology, Anthropology and Linguistics of Emotion. Dordrecht: Kluwer Academic Publishers, 1995. p. 121-143.

GLASER, Barney G.; STRAUSS, Anselm L. Discovery of Grounded Theory: Strategies for Qualitative Research. Mill Valley, CA: Sociology Press, 1967.

GOFFMAN, Erving. Relations in Public: Microstudies of the Public Order. New York: Basic Books, 1971.

The Presentation of Self in Everyday Life. New York: Doubleday Anchor, 1959.

GORDON, Steven. The Sociology of Sentiments and Emotions. In: ROSENBERG, Morris. Social Psychology: Sociological Perspectives. New York: Basic Books, 1981. p. 562-569.

GRAHAME, Peter. Ethnography, Institutions, and the Problematic of the Everyday World. Human Studies, [s.l.], vol. 21, n. 4, p. 347-360, 1998.

GRANDEY, Alicia A. Emotion Regulation in the Workplace: A New Way to Conceptualize Emotional Labour. Journal of Occupational Health Psychology, [s.l.], vol. 5, p. 95-100, 2000.

GRIFFIN, Marie. The Influence of Organizational Climate on Detention Officers' Readiness to Use Force in a County Jail. Criminal Justice Review, [s.l.], vol. 24, n. 1, p. 1-26, 1999.

GRIFFIN, Marie; HOGAN, Nancy; LAMBERT, Eric. Doing 'People Work' in the Prison Setting: An Examination of the Job Characteristics Model and Correctional Staff Burnout. Criminal Justice and Behavior, [s.l.], vol. 39, n. 1, p. 1131-1147, 2012.

GROSSI, Renata. Understanding Law and Emotion. Emotion Review, [s.l.], vol. 7, n. 1, p. 55-60, 2015.

HEARN, Jeff. Emotive Subjects: Organizational Men, Organizational Masculinities and the (De) Construction of "Emotions." In: CZARNIAWSKA, Barbara. Emotion in Organizations. London: Sage, 1993. p. 148-166.

HECHANOVA, Ma Regina. Deconstructing Emotional Labor. Philippine Journal of Psychology, [s.l.], vol. 44, n. 1, p. 76-89, 2011.

HOCHSCHILD, Arlie Russell. Why Are You Rushing? Oprah.com, 2000. Disponível em: <https://www. oprah.com/spirit/why-are-you-rushing>. Acesso em: 26 jun. 2021. 
HOCHSCHILD, Arlie R. The Managed Heart. Berkeley and Los Angeles: University of California Press, 1983.

Emotion Work, Feeling Rules, and Social Structure. American Journal of Sociology, [s.l.], vol. 85 , n. 3, p. $551-575,1979$.

The Sociology of Feeling and Emotion: Selected Possibilities. In: MILLMAN, Marcia; KANTER, Rosabeth M. Another Voice: Feminist Perspectives on Social Life and Social Science. New York: Doubleday, 1975. p. 280-307.

HOGAN, Nancy L; LAMBERT, Eric G; JENKINS, Morris; WAMBOLD, Suzanne. The impact of occupational stressors on correctional staff organizational commitment: A preliminary study. Journal of Contemporary Criminal Justice, [s.l.], vol. 22, n. 1, p. 44-62, 2006.

HOGAN, Nancy; LAMBERT, Eric; GRIFFIN, Marie. Loyalty, Love, and Investments: The Impact of Job Outcomes on the Organizational Commitment of Correctional Staff. Criminal Justice Behavior, [s.l.], vol. 40, n. 1, p. 355-375, 2013.

ILLOUZ, Eva; FINKELMAN, Shoshannah. An Odd and Inseparable Couple: Emotion and Rationality in Partner Selection. Theory and Society, [s.l.], vol. 38, p. 401-422, 2009.

INTERNATIONAL SOCIOLOGICAL ASSOCIATION. Code of Ethics. Madrid: International Sociological Association, 2001. Disponível em: https://www.isa-sociology.org/en/about-isa/code-of-ethics. Acesso em: 26 jun. 2021.

JAKOBY, Nina. Grief as a Social Emotion: Theoretical Perspectives. Death Studies, [s.l.], vol. 36, n. 8, p. 679-711, 2012.

JEFFERSON, Andrew; GABORIT, Liv. Human Rights in Prisons: Comparing Institutional Encounters in Kosovo, Sierra Leone and the Philippines. London: Palgrave Macmillan UK, 2015.

KALINICH, David B; PITCHER, Terry. Dealing With Organizational Stress. National Criminal Justice Reference Service, Illinois: 1984.

KATRIEL, Tamar. Exploring Emotional Discourse. In: FLAM, Helena; KLERES, Jochen. Methods of Exploring Emotions. London: Routledge, 2015. p. 57-66.

KEMPER, Theodore D. (org.). Research Agendas in the Sociology of Emotions. [s.l.]: Suny Press, 1990.

How Many Emotions are There? Wedding the Social and Autonomic Components. American Journal of Sociology, [s.l.], vol. 93, n. 2, p. 263-289, 1987.

Toward a Sociology of Emotions: Some Problems and Some Solutions. The American Sociologist, [s.l.], vol. 13, n. 1, p. 30-41, 1978.

KITZINGER, Jenny. The Methodology of Focus Group: The Importance of Interaction Between Research Participants. Sociology of Health \& Illness, [s.l.], vol. 16, n. 1, p. 103-121, 1994. 
KLEINMAN, Arthur. The Violences of Everyday Life, the Multiple Forms and Dynamics of Social Violence. In: REYNOLDS, Pamela; KLEIMANN, Arthur; RAMPHELE, Mamphela. Violence and Subjectivity. Berkeley: UC Press, 2000. p. 226-241.

KÖVECSES, Zoltán. Emotion Concepts. New York: Springer-Verlag, 1990.

KUSENBACH, Margarethe; LOSEKE, Donileen R. Bringing the Social Back in: Some Suggestions for the Qualitative Study of Emotions. Qualitative Sociology Review, [s.l.], vol. 9, n. 2, p. 21-38, 2013.

LAMBERT, Eric; PAOLINE, Eugene. Exploring Potential Antecedents of Job Involvement: An Exploratory Study Among Jail Staff. Criminal Justice and Behavior, [s.l.], vol. 39, n. 1, p. 264-286, 2012.

LAMBERT, Eric; HOGAN, Nancy; JIANG, Shanhe. Exploring Antecedents of Five Types of Organizational Commitment Among Correctional Staff: It Matters What You Measure. Criminal Justice Policy Review, [s.l.], vol. 19, n. 1, p. 466-490, 2008.

LAMBERT, Eric; HOGAN, Nancy; GRIFFIN, Marie. The Impact of Distributive and Procedural Justice on Correctional Staff Job Stress, Job Satisfaction, and Organizational Commitment. Journal of Criminal Justice, [s.l.], vol. 35, n. 6, p. 644-656, 2007.

LAWLER, Edward J. Bringing Emotions into Social Exchange Theory. Annual review of sociology, [s.l.], vol. 25, p. 217-244, 1999.

LEIP, Leslie; STINCHCOMB, Jeanne. Should I Stay or Should I Go? Job Satisfaction and Turnover Intent of Jail Staff Throughout the United States. Criminal Justice Review, [s.l.], vol. 38, n. 2, p. 226-241, 2013.

LEWIS, J David; WEIGERT, Andrew. Trust as a Social Reality. Social Forces, [s.l.], vol. 63, n. 4, p. 967$985,1985$.

LIEBLING, Alison. Moral Performance, Inhuman and Degrading Treatment and Prison Pain. Punishment \& Society, [s.l.], vol. 13, n. 5, p. 530-550, 2011.

LIEBLING, Alison. Prison Officers, Policing, and the Use of Discretion. Theoretical Criminology, [s.l.], vol. 4, n. 3, p. 333-357, 2000.

LIEBLING, Alison; ARNOLD, Helen. Prisons and Their Moral Performance: A Study of Values, Quality, and Prison Life. Oxford: Clarendon Press, 2004.

LIN, Wei-Lun; TSAI, Ping-Hsun; LIN, Hung-Yu; CHEN, Hsueh-Chih. How Does Emotion Influence Different Creative Performances? The Mediating Role of Cognitive Flexibility. Cognition \& Emotion, [s.l.], vol. 28, n. 5, p. 834-844, 2014.

LIVELY, Kathryn; POWELL, Brian. Emotional Expression at Work and at Home: Domain, Status, or Individual Characteristics? Social Psychology Quarterly, [s.l.], vol. 69, n. 1, p. 17-38, 2006.

LUTZ, Catherine; ABU-LUGHOD, Lila. Language and the Politics of Emotion (Studies in Emotion and Social Interaction). Cambridge: Cambridge, 1990. 
MARCELINO, Elizabeth. Towards Understanding the Psychology of the Filipino. In: ROOT, Maria; BROWN, Laura, Diversity and Complexity in Feminist Therapy. New York: Routledge, 1990. p. 105-128.

MARTIN, Tomas Max; JEFFERSON, Andrew M. Prison Ethnography in Africa: Reflections on a Maturing Field. Politique Africaine, [s.l.], n. 3, p. 131-152, 2019.

McCOY, Alfred. An Anarchy of Families: State and Family in the Philippines. Madison, WI: University of Wisconsin Press, 2009.

MOON, Dawne. Powerful Emotions: Symbolic Power and the (Productive and Punitive) Force of Collective Feeling. Theory and Society, [s.l.], vol. 42, n. 3, p. 261-294, 2013.

NÄRING, Gérard; BRIËT, Mariette; BROUWERS, André. Beyond Demand-control: Emotional Labour and Symptoms of Burnout in Teachers. Work \& Stress, [s.l.], vol. 20, n. 4, p. 303-315, 2006.

NARIO-LOPEZ, Hannah Glimpse. Doing Qualitative Research on Emotional Labor in a Philippine City Jail: Some Methodological Reflections. Philippine Social Sciences Review, [s.l.], vol. 70, n. 1, p. 75-97, 2018.

Emotional Labor Among Officers in a Philippine City Jail. Quezon City: University of the Philippines Diliman, 2017.

NATIONAL JAIL MANAGEMENT \& PENOLOGYTRAINING INSTITUTE (NJMPTI). Philippine Public Safety College. Disponível em: <http://ppsc.gov.ph/2015-03-27-03-54-36/201504-03-00-28-17>. Acesso em: 25 jul. 2020.

NAVARRETE, W. Job Satisfaction of Bureau of Jail Management and Penology Personnel. Philippines: Virgen Delos Remedios College, Olongapo City, 1999.

NICOLAS, J. Social Factors Related to Gang Affiliation and Tattooing among Detainees. Department of Sociology, University of the Philippines, 1988.

O'DONNELL, Ian; EDGAR, Kimmett. Routine Victimisation in Prisons. The Howard Journal of Criminal Justice, [s.l.], vol. 37, n. 3, p. 266-279, 1998.

PATAG, Kristine.PandemicLocks PDLs' Families Out of Prisons. Philstar.com, 2021.Disponívelem:<https:// www.philstar.com/headlines/2021/05/28/2101441/pandemic-locks-pdls-families-out-prisons?fbclid=IwAR3poWd5n5GSVtFoKhPPLek3RTPC3uq8ZtT5dEZK7ZYt3aRYVnbhHVdrTn4>. Acesso em: 26 jun. 2021.

PE-PUA, Rogelia; PROTACIO-MARCELINO, Elizabeth A. Sikolohiyang Pilipino (Filipino Psychology): A Legacy of Virgilio G. Enriquez. Asian Journal of Social Psychology, [s.l.], vol. 3, p. 49-71, 2000.

PÉREZ, Alberto Martín. Emotional Alliances in Bureaucratic Encounters. In: FLAM, Helena; KLERES, Jochen. Methods of Exploring Emotions. London: Routledge, 2015. p. 144-152.

PIWONI, Eunike. Mass-mediated Discourse on Emotion, and the Feeling Rules it Conveys: The Case of the Sarrazin Debate. Current Sociology, [s.l.], vol. 68, n. 3, p. 390-407, 2020. 
RETZINGER, Suzanne. Shame, Anger, and Conflict: Case Study of Emotional Violence. Journal of Family Violence, [s.l.], vol. 6, n. 1, p. 37-59, 1991.

SCHEFF, Thomas J. The Distancing of Emotion in Ritual. Current Anthropology, [s.l.], vol. 18, n. 3, p. 483-490, 1977.

SCHERER, Klaus R. What are Emotions? And How Can They be Measured? Social Science Information, [s.l.], vol. 44, n. 4, p. 695-729, 2005.

SCHERVISH, Paul G; HALNON, Raymond J; HALNON, Karen Bettez. Culture and Emotion in Christmas: The Elementary Forms of Spiritual Life. International Journal of Sociology and Social Policy, [s.l.], vol. 16, n. 9/10, p. 144-170, 1996.

SCOTT, David. Ghosts Beyond Our Realm: A Neo-Abolitionist Analysis of Prisoner Human Rights and Prison Officer Occupational Culture. 2006. Disponívelem: $<\underline{\text { http://clok.uclan.ac.uk/7864/1/Scott, } \% 20}$ David\%20\%20Ghosts.pdf>.

SHAHANI, Nishant. 'Resisting Mundane Violence': Feminism and Queer Identity in Post-Colonial India. Arbor, MI: MPublishing, University of Michigan Library, 2003.

SHILLING, Chris; MELLOR, Philip A. Durkheim, Morality and Modernity: Collective Effervescence, Homo Duplex and the Sources of Moral Action. British Journal of Sociology, [s.l.], vol. 49, n. 2, p. 193209, 1998.

SISLEY, Richard; SMOLLAN, Roy. Emotional Labour and Self-Determination Theory: A Continuum of Extrinsic and Intrinsic Causes of Emotional Expression and Control. New Zealand Journal of Employment Relations, [s.l.], vol. 38, n. 2, p. 41, 2012.

SMITH, Dorothy E. The Everyday World as Problematic, A Feminist Sociology. Toronto: University of Toronto Press, 1987.

STOHR, Mary K; HEMMENS, Craig; KIFER, Misty; SCHOELER, Mary. We Know it, We Just Have to Do it: Perceptions of Ethical Work in Prisons and Jails. The Prison Journal, [s.l.], vol. 80, n. 1, p. 126-150, 2000 .

STRYKER, Sheldon. Identity Theory: Developments and Extensions. In: YARDLEY, Krysia; HONESS, Terry. Self and Identity: Psychosocial perspectives. [s.l.]: John Wiley \& Sons, 1987. p. 89-103.

SYKES, Gresham. The Society of Captives: A Study of a Maximum Security Prison. Princeton: Princeton University Press, 1958.

SYMKOVYCH, Anton. Negative visibility and 'the defences of the weak': The interplay of a managerial culture and prisoner resistance. Theoretical Criminology, [s.l.], vol. 24, n. 2, p. 1-20, 2018.

TAVORY, Iddo; FINE, Gary Alan. Disruption and the Theory of the Interaction Order. Theory and Society, [s.l.], vol. 49, p. 365-385, 2020. 
THEODOSIUS, Catherine. Recovering Emotion from Emotion Management. Sociology, [s.l.], vol. 40, n. 5, p. 893-910, 2006.

THOITS, Peggy. The Sociology of Emotions. Annual Review of Sociology, [s.l.], vol. 15, p. 317-342, 1989.

Coping, Social Support, and Psychological Outcomes: The Central Role of Emotion. Review of Personality \& Social Psychology, [s.l.], vol. 5, p. 219-238, 1984.

THOMAS, Kimberley. The "Mundane Violence" of International Water Conflicts. Education About ASIA, [s.l.], vol. 22, n. 2, p. 36-41, 2017.

UN GENERAL ASSEMBLY. United Nations Standard Minimum Rules for the Treatment of Prisoners (the Nelson Mandela Rules). Vienna, Austria: The Secretariat UN General Assembly, 2015. Disponível em: $<\underline{\text { https://www.unodc.org/documents/justice-and-prison-reform/GA-RESOLUTION/E ebook.pdf }>, ~} 2015$. Acesso em: 26 jun. 2021.

VAN MAANEN, John. Tales of the Field: On Writing Ethnography. Chicago: University of Chicago Press, 1988.

VON SCHEVE, Christian. The Social Calibration of Emotion Expression: An Affective Basis of Microsocial Order. Sociological Theory, [s.l.], vol. 30, n. 1, p. 1-14, 2012.

WESTMARLAND, Louise. Blowing the Whistle on Police Violence. Gender, Ethnography, and Ethics. British Journal of Criminology, [s.l.], vol. 41, n. 3, p. 523-535, 2001.

YACAT, Jay. Tungo sa Isang Mas MapagbuongSikolohiya: Hamon sa Makabagong Sikolohiyang Pilipino. Daluyan: Journal ng Wikang Filipino, [s.l.], vol. 19, n. 2, p. 5-32, 2013.

ZAHAVI, Dan; OVERGAARD, Søren. Intersubjectivity. In: LAFOLLETTE, Hugh (ed.). International Encyclopedia of Ethics. [s.l.]: Wiley-Blackwell, 2013. p. 1-11.

Declaration of No Conflict of Interest: The author declares that she has no conflict of interest.

Data Availability Statement and Additional Ethical Measures: Since the conduct of this study, jail officers who participated in the study have been assigned to different posts. The author ensures that traceability of identities are protected by close observation of anonymity, confidentiality, and belated publication of this research. All copies of classified jail documents under the custody of the researcher during the data gathering stage have been destroyed.

Funding: The author received funding for her MA thesis, which served as the 'main data gathering stage' of this study, from the Commission on Higher Education, Philippines, University of the Philippines-Diliman Office of the Vice Chancellor for Research and Development, and Philippine Social Sciences Council. 